\title{
Temporal variation in estrogen receptor- $\alpha$ protein turnover in the presence of estrogen
}

\author{
Christopher C Valley, Natalia M Solodin, Ginny L Powers, Stephanie J Ellison \\ and Elaine T Alarid
}

\author{
McArdle Laboratories for Cancer Research, Department of Oncology, School of Medicine and Public Health, University of Wisconsin-Madison, 1400 University Avenue, \\ Madison, Wisconsin 53706, USA \\ (Correspondence should be addressed to E T Alarid; Email: alarid@oncology.wisc.edu)
}

\begin{abstract}
Estrogen receptor- $\alpha(E R \alpha)$ is essential in the maintenance of cellular responsiveness to estrogen in the reproductive system. It is established that ligand binding induces downregulation of ER $\alpha$ protein by targeting receptor for destruction by the $26 \mathrm{~S}$ proteasome. However, $\mathrm{ER} \alpha$ is preserved in cells chronically exposed to estrogen and it is unknown how receptor levels are maintained in the continued presence of the signal that induces degradation. A modified pulsechase analysis was developed using a tet-inducible $\mathrm{ER} \alpha$ expression system to determine the rate of ER $\alpha$ protein decay following both acute and chronic estrogen treatments. Upon initial hormone treatment, ER $\alpha$ half-life is shortened from 3 to $1 \mathrm{~h}$. However, ER $\alpha$ half-life increases over time, achieving a half-life of $\sim 6 \mathrm{~h}$ in $72 \mathrm{~h}$ of estrogen treatment. Analysis of $E R \alpha$ half-life in the presence and absence of proteasome inhibitor, MG132, revealed that the increased stability is due in part to a decreased rate of proteolysis. In addition, we observed a time-dependent increase in phospho-S118 $\mathrm{ER} \alpha$ and showed that the half-life of the phosphomimetic ER $\alpha$ mutant, S118E-ER, is identical to that of wild-type receptor under conditions of chronic estrogen treatment. These data provide evidence that as cells adapt to chronic stimulation, ER $\alpha$ protein is stabilized due first to a decreased rate of proteolysis, and secondarily, to the accumulation of proteasome-resistant, phosphorylated form of receptor. This temporal control of proteolysis allows for the establishment of steady-state levels of receptor and provides a protective mechanism against loss of hormone responsiveness.
\end{abstract}

Journal of Molecular Endocrinology (2008) 40, 23-34

\section{Introduction}

Estrogen receptor- $\alpha(\mathrm{ER} \alpha)$ is the predominant of two ERs, $\alpha$ and $\beta$, that mediate the actions of estrogen in the reproductive system. It functions as a transcriptional regulator, inducing cellular responses through the regulation of gene expression. The majority of our knowledge of estrogen action comes from the analysis of $\mathrm{ER} \alpha$ transcriptional activity. It has been shown that ER $\alpha$ mediated transcription occurs in a well-ordered sequence of events (Shang et al. 2000, Métivier et al. 2003). These include the stable binding of receptor to DNA, recruitment of coactivator and chromatin remodeling complexes, and ultimately the recruitment of the basal transcriptional machinery. The orchestration of these events leads to gene-specific regulation with some targets being transiently induced while others, once upregulated, remaining high. The temporal regulation of gene expression mediated by ER $\alpha$ is critical in the timing of varied responses to estrogen, ranging from the induction of proliferation and differentiation to the maintenance of the menstrual cycle (Frasor et al. 2003, Hewitt et al. 2003).

In addition to gene expression, estrogen also induces another less well-understood cellular response, autoregulation of ER $\alpha$ protein. Feedback regulation of $\mathrm{ER} \alpha$ by estrogen has been observed in a number of cell contexts in the reproductive system including the pituitary and mammary gland and in a number of breast and uterine cancer cell lines (Cidlowski \& Muldoon 1978, Horigome et al. 1988, Read et al. 1989, Saceda et al. 1989, Kaneko et al. 1993, Keaveney et al. 1993). While negative regulation of $\mathrm{ER} \alpha$ can be controlled at multiple levels, estrogen directly regulates $\mathrm{ER} \alpha$ protein by targeting receptor for degradation by the $26 \mathrm{~S}$ proteasome (Alarid et al. 1999, El Khissiin \& Leclercq 1999, Nawaz et al. 1999). Proteolysis of $\mathrm{ER} \alpha$ is initiated upon ligand binding (Preisler-Mashek et al. 2002), and like other targets of the 26S proteasome, ER $\alpha$ becomes ubiquitinated and subsequently degraded (Wijayaratne \& McDonnell 2001). Mutational analysis has identified two key structural elements that are essential for estrogeninduced proteolysis, both of which are contained within transactivation domains. Specifically, substitutions at phosphorylation site, S118, in activation function-1 (AF-1), and residues I358, K362, V376, and L539 in the coactivator interaction surface of activation function-2 (AF-2) abolish ligand-induced degradation of $\mathrm{ER} \alpha$ (Lonard et al. 2000, Valley et al. 2005). Beyond the

DOI: 10.1677/JME-07-0067 Online version via http://www.endocrinology-journals.org 
identification of these essential elements, very little is understood about the signaling events that target estrogen-bound receptor for degradation.

Previous studies have shown that estrogen-induced downregulation of $\mathrm{ER} \alpha$ is an acute response to estrogen resulting in a drop of $\sim 50 \%$ of the total receptor content within the first hours of estrogen treatment (Pink \& Jordan 1996). Subsequently, cells establish a lower steadystate level of receptor. Curiously, despite the continued presence of the signal that induces both receptor proteolysis and decreased receptor synthesis, cells are not depleted of receptor. How cells maintain ER $\alpha$ protein levels in the presence of chronic estrogen treatment is unknown. To address this question, it is necessary to measure the half-life of $\mathrm{ER} \alpha$ protein at different times following estrogen exposure. Two major strategies are used to examine the turnover rate of proteins: conventional pulse-chase analysis and pretreatment with protein synthesis inhibitors. By pulse-chase analysis, the basal halflife of ER $\alpha$ ranges from 3 to $5 \mathrm{~h}$, depending on the cell type (Alarid 2006). Estrogen treatment significantly shortens the half-life of ER $\alpha$ to as little as $1 \mathrm{~h}$ (Alarid et al. 1999). This method is limited to the measurement of acute changes in $\mathrm{ER} \alpha$ half-life due to technical issues related to deprivation of essential amino acids and pulse labeling of cells. The alternative approach is to block protein synthesis with inhibitors, such as cycloheximide, and measures protein decay by western blot analysis. The latter, however, cannot be applied to the study of ER $\alpha$ since protein synthesis inhibitors prevent ligand-induced turnover of the receptor (Borras et al. 1994). To overcome these challenges, we developed a modified pulse-chase method that takes advantage of tetracycline-dependent expression of an epitope-tagged ER $\alpha$ in a breast cancer model system. In this model, a pool of hemagglutinin (HA)-tagged ER $\alpha$ (ERHA) is synthesized upon treatment of cells with doxycycline (Dox; Fowler et al. 2004). Removal of Dox results in a cessation of ERHA synthesis, and ERHA protein decay can be monitored by western blot analysis. This model was utilized to examine the rate of $\mathrm{ER} \alpha$ proteolysis following both short- and long-term estrogen exposures.

\section{Materials and methods}

\section{Cell culture}

A tet-inducible derivative of MCF7 breast cancer cells was engineered to express HA-tagged versions of either wildtype ER $\alpha$ or a phosphomimetic mutant, S118E-ER $\alpha$, when treated with Dox. The tet-on MCF7 cell line overexpressing wild-type ER $\alpha$ (ERHA) was described previously (Fowler et al. 2004). Cells with tet-inducible expression of S118E-ERHA were created similarly. Briefly, S118E-ERHA was subcloned into the pUHD10-3 vector
(Gossen et al. 1995) downstream of the tet-resistance operator. The resultant plasmid was cotransfected with a plasmid conferring puromycin resistance into a tet-responsive parental MCF7 cell line (Fowler et al. 2004). Clones were selected with puromycin and screened for induction of HA-tagged receptor in the presence of $1 \mu \mathrm{g} / \mathrm{ml}$ Dox by western blot analysis. Cells were maintained under standard culture conditions in a water-jacketed incubator at $37^{\circ} \mathrm{C}, 10 \% \mathrm{CO}_{2}$. Growth media consisted of Dulbecco's modified Eagle's medium (DMEM; Mediatech Inc., Herndon, VA, USA) supplemented with $10 \%$ fetal bovine serum, 100 units $/ \mathrm{ml}$ penicillin $\mathrm{G}$, and $100 \mu \mathrm{g} / \mathrm{ml}$ streptomycin (GIBCO). For experiments involving estrogen treatment, cells were transferred to phenol red-free DMEM with $10 \%$ charcoal/dextran-stripped fetal bovine serum, $100 \mathrm{units} / \mathrm{ml}$ penicillin $\mathrm{G}$, and $100 \mu \mathrm{g} / \mathrm{ml}$ streptomycin, and L-glutamine prior to treatment with ethanol (EtOH) or $10 \mathrm{nM} 17 \beta$-estradiol $\left(\mathrm{E}_{2}\right)$. Experiments using proteasome inhibitor consisted of a 30 -min pretreatment with $10 \mu \mathrm{M}$ MG132.

\section{Western blot analysis}

Western analysis was conducted on whole cell lysates. Following treatment, cells were washed with PBS and lysed directly in sample buffer consisting of $6.5 \mathrm{mM}$ Tris, $\mathrm{pH}$ $6 \cdot 8,2 \%$ SDS, $10 \%$ glycerol, and $5 \% \beta$-mercaptoethanol. Proteins were separated by gel electrophoresis on a $7.5 \%$ acrylamide gel and transferred to polyvinylidene flouride (PVDF) membrane (Millipore, Piscataway, NJ, USA). ERHA, ER $\alpha$, and phospho-S118 ER $\alpha$ protein were detected with anti-HA antibody (Y-11), anti-ER $\alpha$ (HC-20; Santa Cruz Biotechnology, Santa Cruz, CA, USA), and anti-pS118ER $\alpha$ (Cell Signaling Technology Inc., Boston, MA, USA). The HC-20 antibody detects both HA-tagged and endogenous receptors. Bands were visualized by a chemiluminescence detection method (Amersham Biosciences). Receptor protein levels were measured by densitometry using Bio-Rad Quantity One Software (Bio-Rad). To quantify $\mathrm{ER} \alpha$ protein levels, a standard curve was generated for each experiment using serial dilutions of control samples. Only exposures where the $r$ values for standard curves were $>0.980$ were used in the analysis of ERHA and $\mathrm{ER} \alpha$ protein values. Linear regression analysis was then performed to determine the amounts of $\mathrm{ER} \alpha$ protein relative to the control sample. Each point and error bars represent the mean and standard error of the three independent experiments.

\section{Half-life measurements}

Pulse-chase analysis was carried out as previously described (Alarid et al. 1999). In short, cells were 
metabolically labeled with $100 \mu \mathrm{Ci} / \mathrm{ml}{ }^{35} \mathrm{~S}$-methionine for $1 \mathrm{~h}$ in DMEM cys ${ }^{-} / \mathrm{met}^{-}$medium. Cells were then washed with growth media consisting of phenol red-free DMEM with $10 \%$ charcoal/dextran-treated fetal bovine serum and aliquoted. Treatment consisted of either $\mathrm{EtOH}$ or $\mathrm{E}_{2}$ for the indicated length of time. ${ }^{35} \mathrm{~S}-\mathrm{ER} \alpha$ protein was isolated through two rounds of immunoprecipitation using anti-ER $\alpha$ (HC-20) antibody and separated by gel electrophoresis. Protein bands were quantified by phosphoimager analysis using ImageQuant software (Molecular Dynamics Inc., Sunnyrale, CA, USA).

To determine the half-life of ERHA (wild-type and S118E) protein, a modified pulse-chase method was developed based on the induction of ERHA with Dox. In this method, a pool of ERHA was synthesized by the treatment of ERHA cells with $1 \mu \mathrm{g} / \mathrm{ml}$ Dox for $24 \mathrm{~h}$. Previous studies showed that this dose and time are sufficient for maximum induction of ERHA (Fowler et al. 2004). Cells were then washed thrice with PBS, trypsinized, resuspended in phenol red-free DMEM with $10 \% \mathrm{charcoal} /$ dextran-stripped serum, and aliquoted into groups. Cells were subsequently treated with $\mathrm{EtOH}$ or $\mathrm{E}_{2}$ as in a traditional pulse chase for the length of time indicated in the individual figures. Changes in ERHA and endogenous ER $\alpha$ protein levels were determined by western blot analysis as described above. A schematic of four different treatment groups is presented in Fig. 1A. Data represent the mean and standard error for three independent experiments.

\section{Quantitative real-time PCR}

Total RNA was isolated using the Qiagen RNeasy Mini Kit according to the manufacturer's protocol and treated with DNAse (Qiagen). RNA ( $1 \mu \mathrm{g})$ was reverse transcribed (iScript, Bio-Rad Laboratories) in a total reaction volume of $20 \mu \mathrm{l}$. The resulting cDNA was diluted to a volume of $100 \mu \mathrm{l}$ with nuclease-free water. For real-time PCR analysis, $1 \mu \mathrm{l}$ diluted cDNA was used in a $25 \mu \mathrm{l}$ reaction consisting of $100 \mathrm{nM}$ forward and reverse primers and $1 \times$ IQ SYBR Green Supermix (Bio$\mathrm{Rad}$ Laboratories). Thermocycling was performed using an annealing temperature of $60^{\circ} \mathrm{C}$ for $\mathrm{P} 0$ primers and $57^{\circ} \mathrm{C}$ for ERHA and ER $\alpha$ primers. Ribosomal protein P0 mRNA was used as the internal control. Relative mRNA levels were calculated using the $\Delta \Delta C_{\mathrm{t}}$ method (Livak \& Schmittgen 2001). Primer sequences used are as follows: ERHA forward, $5^{\prime}$-ACAAGCTCGCGTAATCTGG; ERHA reverse, $5^{\prime}$-CTGCGGGCTCTACTTCATC; ER $\alpha$ forward, 5'-CTCTAACCTCGGGCTGTG; ER $\alpha$ reverse, 5'-CTTGGATCTGATGCAGTAGG; P0 forward, 5'-GACAATGGCAGCATCTACAAC; and P0 reverse, 5'-GCAGACAGACACTGGCAAC. The primers for detection of endogenous ER $\alpha$ amplify a region of the $5^{\prime}$ untranslated region $(+263 /+420)$ that is not contained in the ERHA mRNA. Primers for ERHA
mRNA amplify a region containing the HA sequence $(+2071 /+2190)$, thereby distinguishing the amplicon from endogenous $\mathrm{ER} \alpha$.

\section{Calculation of ERHA synthesis and proteolysis}

Mathematically, protein turnover or total change in receptor level can be defined as the sum change resulting from ERHA protein production, i.e., synthesis, and ERHA proteolysis as described in Equation 1.

$\Sigma(\text { total change })_{\mathrm{ER} \alpha}$

$$
=\Sigma(\text { synthesis })_{\mathrm{ER} \alpha}+\Sigma(\text { proteolysis })_{\mathrm{ER} \alpha}
$$

In this equation, synthesis would be a net gain in receptors and would therefore be positive number. A net loss of receptor by proteolysis would be represented as a negative number. Treatment of cells with MG132 inhibits ER $\alpha$ proteolysis. Therefore, in the presence of MG132, proteolysis can be neglected. Under such conditions,

$\Sigma(\text { total change })_{\mathrm{ER} \alpha}=\Sigma(\text { synthesis })_{\mathrm{ER} \alpha}$

Application of this concept allows us to determine a value for $\mathrm{ER} \alpha$ synthesis between time points $0-2,2-4,4-$ 6 , and $6-8 \mathrm{~h}$ in experiments conducted with proteasome inhibitor.

Equation 1 can be rearranged to allow determination of the amount of ER $\alpha$ proteolysis in the absence of proteasome inhibitor as follows:

$$
\begin{aligned}
& \Sigma(\text { proteolysis })_{\mathrm{ER} \alpha} \\
& \quad=\Sigma(\text { total change })_{\mathrm{ER} \alpha}-\Sigma(\text { synthesis })_{\mathrm{ER} \alpha}
\end{aligned}
$$

where $\Sigma$ (total change) $)_{\mathrm{ER} \alpha}$ equals the total change in $\mathrm{ER} \alpha$ level measured in the absence of MG132 and $\Sigma$ (synthesis) $)_{\mathrm{ER} \alpha}$ equals the amount of synthesis determined from Equation 2. These calculations were used to determine the relative contribution of synthesis and proteolysis to the establishment of receptor levels upon acute and chronic treatments with estrogen. The values and calculations of ERHA proteolysis over the 8-h chase for each group are described in detail in the supplementary data (Supplemental Table 1, which can be viewed online at http://jme.endocrinology-journals. org/content/vol40/issuel/).

\section{Results}

Estrogens can elicit both transient and persistent cellular responses. Treatment of cells with estrogen results in the activation of expression of multiple target genes. For some ER $\alpha$ gene targets, such as pS2 and PR, induction of gene expression is rapid and sustained for as long as estrogen is present. c-myc and cyclin D1, ER $\alpha$-mediated gene expression is transient (Frasor et al. 2003). Like 

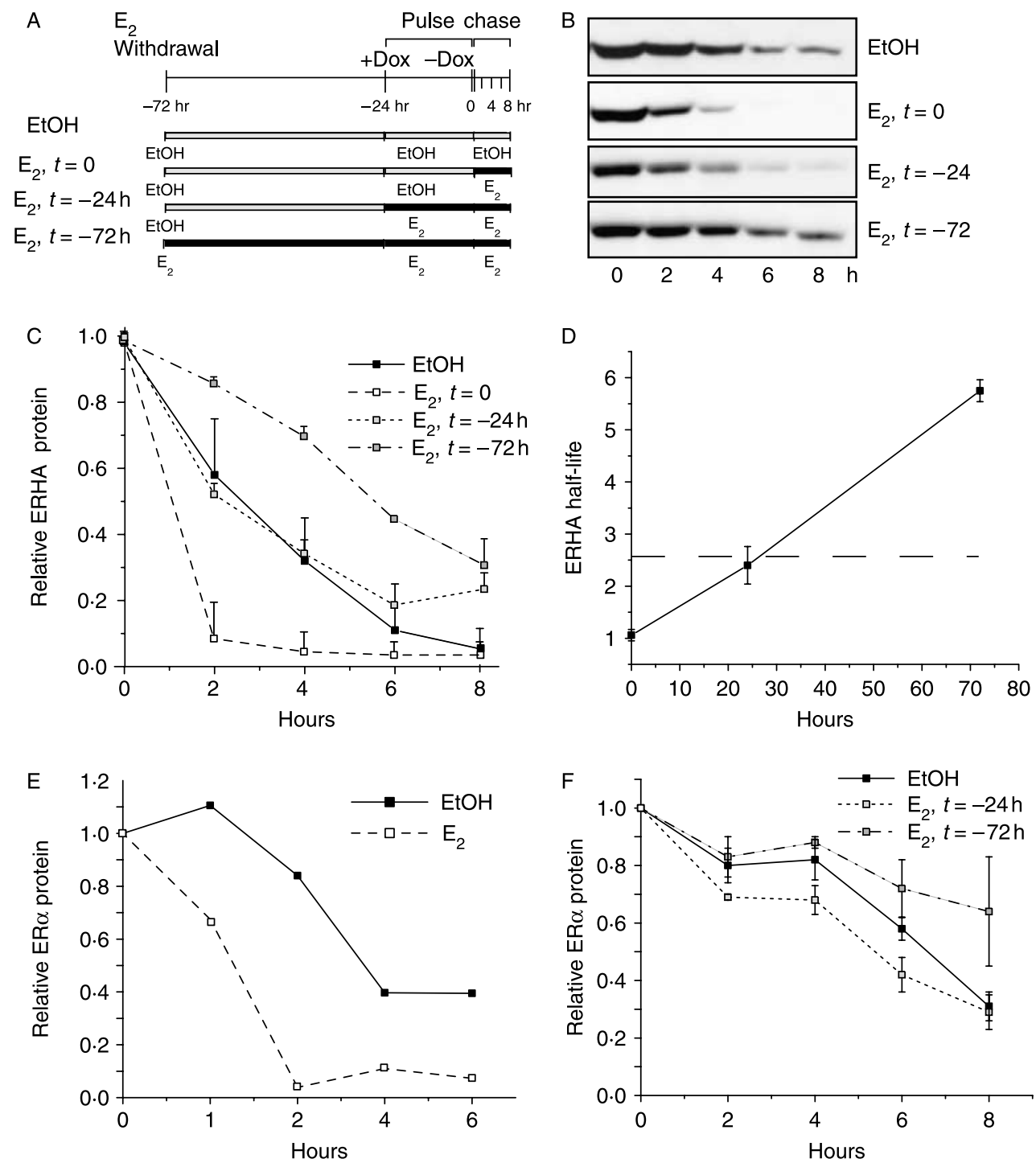

Figure $1 \mathrm{ER} \alpha$ turnover rate at different times of pre-exposure to estrogen. (A) Schematic of the tet-inducible pulse-chase protocol for four groups pretreated for varying lengths of time with estrogen. Experiments were conducted in phenol red-free DMEM with charcoal/dextran-stripped serum. Controls included vehicle treatment of $0.1 \%$ ethanol $(E t O H)$. Estrogen treatment $\left(E_{2}\right)$ consisted of $10 \mathrm{nM} 17 \beta$-estradiol. (B) Representative western blot on whole cell lysates showing changes in ERHA protein over the chase period following removal of Dox $(0,2,4,6$, and $8 \mathrm{~h})$. (C) Levels of ERHA protein were quantified by densitometry and relative levels were determined by linear regression analysis against a standard curve generated for each blot where signal intensity at $t=0$ was set at $1 \cdot 0$. Data shown represent the mean + S.E.M. for three independent experiments. (D) The half-life of ERHA protein is plotted relative to the time of estrogen exposure. The basal half-life of receptor (EtOH-treated control) is represented by the dashed line. Data represent the mean \pm s.E.M. of three independent experiments. (E) Traditional pulse-chase analysis of $E R \alpha$ protein levels was carried out as described in Material and methods section. Following ${ }^{35} \mathrm{~S}$-labeling, cells were maintained in the absence $(\mathrm{EtOH})$ and presence of $\mathrm{E}_{2}$ for the indicated length of time. ER $\alpha$ protein was immunoprecipitated, separated by gel electrophoresis, and quantified by phosphoimager analysis. Pulsechase analysis was performed once and is consistent with previously published results. (Pakdel et al. 1993, Alarid et al. 1999). (F) Western blots from $C$ were reprobed with anti-ER $\alpha$ antibody (HC20) to examine endogenous $E R \alpha$ levels. Relative levels of $E R \alpha$ were determined as described in $1 C$. Data are presented as the mean \pm S.E.M. of three independent experiments. 
induction of gene expression, it is known that proteolysis of $\mathrm{ER} \alpha$ is a rapid response to ligand stimulation, but it is unknown whether proteolysis is a transient or long-term response. We set out to measure the half-life of ER $\alpha$ protein at different time points following $\mathrm{E}_{2}$ treatment. A modified pulse-chase protocol was developed which takes advantage of a tet-inducible ER $\alpha$ expression system. We previously created a tet-on MCF7 cell line in which treatment with Dox results in the induction of ERHA protein (Fowler et al. 2004). Since induction of ERHA production is dependent on Dox, we reasoned that a treatment with Dox would generate a pool of presynthesized HA-tagged receptor akin to pulse labeling of receptor with radioactivity. After $24 \mathrm{~h}$ of antibiotic treatment, Dox could be washed out, and the ensuing loss of ERHA protein would reflect the decay of the HA-tagged protein, analogous to protein turnover that occurs during the 'chase' period of a traditional pulse chase. To test this idea, cells received a 'pulse' of Dox for $24 \mathrm{~h}$. Subsequently, Dox was removed by rigorous washing with PBS, trypsinization, and media change. Cells were then aliquoted into vehicle $(\mathrm{EtOH})$ or estrogen $\left(\mathrm{E}_{2}\right)$ treated groups and collected at 2-h intervals for $8 \mathrm{~h}$. To compare the effect of short- and long-term hormone treatments on ER $\alpha$ protein turnover, cells were pretreated for various lengths of time $(0,24$, and $72 \mathrm{~h})$ with estrogen or vehicle control (EtOH) prior to the pulse of Dox. A schematic of the treatment protocols for each group is shown in Fig. 1A. Changes in ERHA protein levels were assessed by western blot analysis. Figure 1B shows that ERHA protein levels decline at varying rates depending on the length of time of pre-exposure to estrogen. Quantification of ERHA protein levels over time is shown in Fig. 1C. In the absence of estrogen (EtOH), ERHA protein is lost gradually over $8 \mathrm{~h}$ with an approximate halflife of $2 \cdot 6 \mathrm{~h}$. Addition of estrogen during the chase period $\left(\mathrm{E}_{2}, t=0\right)$ resulted in a more rapid turnover of ERHA with a half-life of $\sim 1 \mathrm{~h}$.

For comparison, a traditional pulse-chase analysis was performed to measure the half-life of endogenous ER $\alpha$ in the same cell system (Fig. 1E). ${ }^{35}$ S-labeled ER $\alpha$ protein decayed with the basal half-life of $\sim 3.5 \mathrm{~h}$ and estrogen treatment shortened the half-life to $1.3 \mathrm{~h}$. The half-life of ERHA and endogenous ER $\alpha$ proteins determined by the tet-inducible model and classical pulse chase respectively are comparable and are consistent with previous estimates of receptor half-life (Eckert et al. 1984, Monsma et al. 1984, Alarid et al. 1999). These results show that the turnover of ERHA accurately reflects the regulation of endogenous receptor protein.

In Fig. 1D, the half-life of ERHA is plotted against the time of estrogen treatment. The data reveal that the ERHA protein half-life increases more than fivefold, as cells are maintained in the estrogen. Interestingly, the half-life of ERHA at $24 \mathrm{~h}$ is similar to the basal half-life of the receptor, shown as the dashed line. This time point was of particular interest since analysis of ER $\alpha$ transcriptional activity by reporter gene assays is typically measured following this length of time of estrogen treatment. By $72 \mathrm{~h}$, ERHA protein is greatly stabilized and the half-life is $\sim 5 \cdot 6 \mathrm{~h}$, close to double the basal level. Examination of endogenous ER $\alpha$ protein at later time points of estrogen pretreatment in Fig. $1 \mathrm{~F}$ showed that endogenous receptor levels also fell during the chase period, though to a lesser extent than ERHA.

Chronic estrogen treatment results in the establishment of lower steady-state levels of receptor in a cell. To further compare the regulation of ERHA and endogenous ER $\alpha$, steady-state levels of HA-tagged and endogenous receptor were determined. Cells were treated with estrogen for 0,24 , and $72 \mathrm{~h}$, and the levels of HA-tagged and endogenous receptors were assessed by western blot analysis. Quantification of the relative receptor levels in Fig. 2A shows that ERHA and endogenous receptor are decreased similarly by estrogen treatment. Further, there is no significant difference between groups treated for 24 and $72 \mathrm{~h}$, consistent with receptor levels having reached a steady-state level with chronic hormone treatment. When the mRNA levels of ERHA and endogenous receptor were examined by quantitative PCR, we found that the ERHA mRNA is increased $\sim 14$-fold by Dox treatment in both absence and presence of estrogen (Fig. 2B). Withdrawal of Dox resulted in a decline in ERHA but not endogenous ER $\alpha$ expression. These data demonstrate that the tet-induced ERHA protein is regulated along with the endogenous $\mathrm{ER} \alpha$ protein, and this regulation is independent of the expression level. Examination of Fig. 2B also shows that ERHA mRNA expression is dependent of Dox, while endogenous ER $\alpha$ is unchanged by removal of Dox. The maintenance of synthesis of endogenous ER $\alpha$ during the chase period could offset decreases induced by protein turnover and explain the apparent increased stability of the endogenous receptor protein relative to ERHA in tet-inducible pulse-chase experiments (Fig. 1F).

We reasoned that the increased stability of ERHA under conditions of chronic estrogen treatment could be explained if estrogen-induced proteolysis of $\mathrm{ER} \alpha$ was a transient response and had ended by $24 \mathrm{~h}$. It has been established that estrogen-induced ER $\alpha$ degradation is mediated by the ubiquitin-proteasome pathway, and this process is effectively blocked by pharmacologic inhibitors of the 26S proteasome, such as ALLnL, lactacystin, and MG132 (Alarid et al. 1999, Nawaz et al. 1999, Reid et al. 2003). We postulated that if proteasome-dependent proteolysis of receptor had ceased, then inhibition of proteasome activity would have no effect on ERHA protein turnover at later time points. Pulse-chase experiments were conducted as before in the presence of MG132 (Fig. 3A). Consistent with previous reports, proteasome inhibition abolished the basal $(\mathrm{EtOH})$ and 

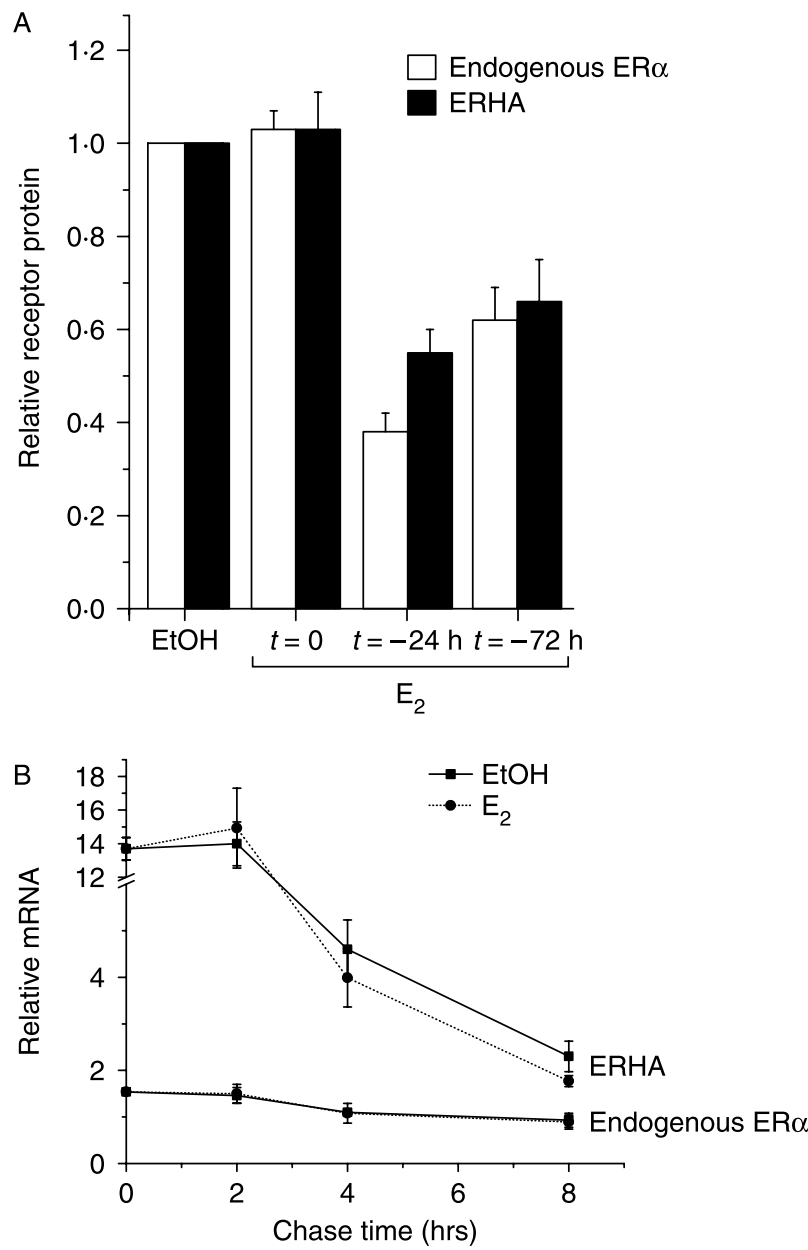

Figure 2 Coordinate regulation of ERHA and endogenous ER $\alpha$ protein. (A) Cells from treatment groups described in Fig. 1A were harvested immediately following the Dox pulse. Western blot analysis was performed on whole cell lysates, probing for the inducible HA tagged (ERHA) with anti-HA antibody and for endogenous receptor $(E R \alpha)$ with anti-ER $\alpha$ antibody. Relative levels of receptor were quantified as described in Materials and methods. Data shown are the mean \pm S.E.M. for three independent experiments. (B) Cells were treated with $1 \mu \mathrm{g} / \mathrm{ml}$ Dox for $24 \mathrm{~h}$ followed by $\mathrm{EtOH}$ or $10 \mathrm{nM} \mathrm{E}_{2}$ for $0,2,4$, and $8 \mathrm{~h}$. Total RNA was isolated and quantitative RT-PCR was performed using primers specific to ERHA and endogenous $E R \alpha$. ERHA mRNA levels were normalized to the internal control PO gene and calculated relative to a control sample not induced with Dox.

estrogen-induced degradation of ERHA $\left(\mathrm{E}_{2}, t=0\right.$; Alarid et al. 1999, El Khissiin \& Leclercq 1999, Lonard et al. 2000, Tateishi et al. 2004, Fan et al. 2005). At 24 and $72 \mathrm{~h}$ of estrogen exposure, inhibition of proteasome activity also prevented loss of ERHA protein and surprisingly, resulted in an increase in ERHA protein. The increase in receptor in the presence of MG132 was also observed with endogenous ER $\alpha$ (Fig. 3B). Results in Fig. 3C and D show that MG132 treatment did not differentially alter ERHA and ER $\alpha$ mRNA among the four treatment groups.
Thus, the increase in protein levels at 24 and $72 \mathrm{~h}$ cannot be attributed to an increase in receptor expression. It is uncertain at this point why $\mathrm{ER} \alpha$ protein accumulates under these conditions. However, since MG132 inhibited the loss of receptor under all conditions, this implies that proteolysis is on-going at 24 and $72 \mathrm{~h}$ and hence, ER $\alpha$ degradation is sustained in the presence of estrogen.

Total receptor protein levels in the cell are achieved through a balance of receptor synthesis and degradation. This can be mathematically represented as the sum of $\mathrm{ER} \alpha$ protein synthesis and $\mathrm{ER} \alpha$ proteolysis, where positive changes represent a net gain in receptor and negative changes indicate a net loss of receptor as described in Materials and methods. Based on this simple concept, one could determine a value for either the synthesis or degradation of receptor by measuring the total change in receptor under conditions where either one of the processes was inhibited. This concept is the basis for the use of cycloheximide where the inhibition of new protein synthesis allows for the assessment of protein degradation. In our model, proteolysis is inhibited by the proteasome inhibitor, MG132, and thus the total change in receptor provides an estimate for the amount of receptor protein synthesis that occurs. Taking data from experiments described in Fig. 3, we calculated the amount of protein synthesis between 0-2, 2-4, and 4-8 $\mathrm{h}$ in the presence of MG132 (Supplemental Table 1). Examination of the incremental changes between each time point in the EtOHtreated group shows a net overall increase of 18 relative receptor units over the 8 -h chase period (ex. 11-2+9), and this number increased to $\sim 25$ relative receptor units upon addition of estrogen. After 24 and $72 \mathrm{~h}$, the overall net increase in synthesis further increased to $\sim 64$ and 102 relative receptor units respectively.

Given values for the amount of receptor synthesis between each collected time point, we then calculated the relative receptor units degraded by taking the total change in receptor (in the absence of inhibitors) and subtracting the amount of receptor synthesized as described in Equation 3 in Materials and methods. As an example, under basal conditions (EtOH-treated group), the measured amount of ERHA in the absence of MG132 at times 0 and $2 \mathrm{~h}$ are 98 and 58 respectively. Thus, the incremental change in ERHA between 0 and $2 \mathrm{~h}$ is $58-98=-40$ (a net loss of receptors). The measured amount of ERHA in the presence of MG132 at 0 and $2 \mathrm{~h}$ are 100 and 111 , with a net increase of 11 receptor units $(111-100=11)$. From these numbers, we can calculate the amount of receptor change due to proteolysis; total receptor - synthesized $=-40-11=-51$. These calculations were carried out for each group of estrogen-treated samples as described in Fig. 1A, adjusting for the relative starting values of receptor (Supplemental Table 1). 

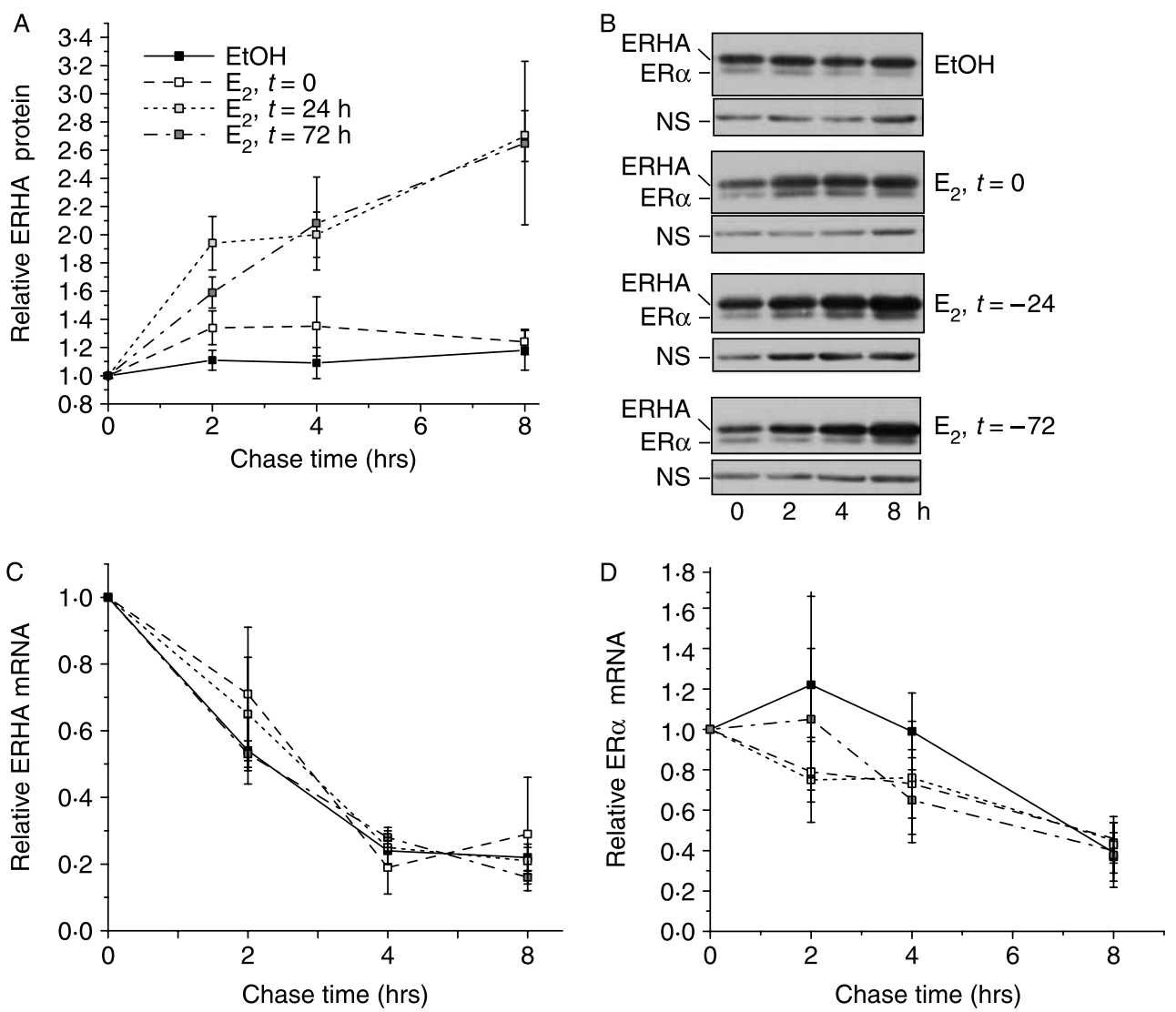

Figure 3 Estrogen-induced loss of ERHA protein is reversed in the absence of proteasome-mediated proteolysis. (A) Cells were treated as described in Fig. 1A. In the last $30 \mathrm{~min}$ of Dox induction, cells were treated with $10 \mu \mathrm{M}$ MG132. ERHA protein was assessed by western blot analysis. Relative levels of ERHA protein were quantified as described in Materials and methods. Data are presented as the mean \pm S.E.M. of three independent experiments. (B) Representative western blots for groups in A were probed with anti$\mathrm{ER} \alpha(\mathrm{HC} 20)$ antibody. The anti-ER $\alpha$ antibody detects both the ERHA and the endogenous $\mathrm{ER} \alpha$ protein. The ERHA protein (upper band) has a slowed migration due to the presence of the C-terminal HA-tag relative to the endogenous $E R \alpha$ protein (lower band). A nonspecific band serves as a loading control. Total RNA was isolated from cells treated as in (A) and quantitative RT-PCR was performed using primers specific to ERHA (C) and endogenous ER $\alpha$ (D). ERHA and ER $\alpha$ mRNA levels were normalized to the internal control P0 gene and calculated relative to mRNA levels determined at $t=0$. Data represent the mean \pm S.E.M. of three independent experiments.

Figure 4A-D shows the calculated values of ERHA protein at times 2,4 , and $8 \mathrm{~h}$ due to receptor proteolysis and the corresponding trend lines based on a secondorder polynomial equations (correlation coefficients $r^{2}>0.9$ ). The first derivative of the proteolysis data trend lines for ERHA levels in Fig. $4 \mathrm{~A}-\mathrm{D}, \mathrm{d} y / \mathrm{d} x$ or $\mathrm{d}$ (ER protein) $/ \mathrm{d} t$, yields the rate of proteolysis for time points between 0 and $8 \mathrm{~h}$ with units of relative receptors degraded per hour (Fig. 4E). The y-intercept, at $t=0 \mathrm{~h}$, indicates the calculated initial rate of ERHA proteolysis for each group at the start of the chase, and the graph illustrates the change in the rate of proteolysis during the 8-h chase. Acute $\mathrm{E}_{2}$ treatment results in the highest initial rate of proteolysis of $\sim 60$ relative receptors degraded per hour. The ERHA levels at subsequent time points within the $\mathrm{E}_{2}, t=0$ group are not accurately described by the trend lines since receptor levels were close to the level of detection of the assay and thus the rate of proteolysis was not interpreted further. The rates of proteolysis of ERHA in the absence of estrogen and that of groups exposed to estrogen for 24 and $72 \mathrm{~h}\left(\mathrm{EtOH} ; \mathrm{E}_{2}, t=24\right.$; and $\mathrm{E}_{2}, t=72$ respectively) were approximately equal, with estimated initial proteolysis rates of $\sim 25$ relative receptors degraded per hour at $t=0$ and ranged from 10 to 20 relative receptors degraded at $t=8 \mathrm{~h}$. These data imply that estrogen-induced proteolysis is slowed at later time points of estrogen exposure. However, the lack of difference between the rate of proteolysis at 24 and $72 \mathrm{~h}$ indicates that another mechanism must be invoked to explain the increased half-life of receptor between 24 and $72 \mathrm{~h}$. 

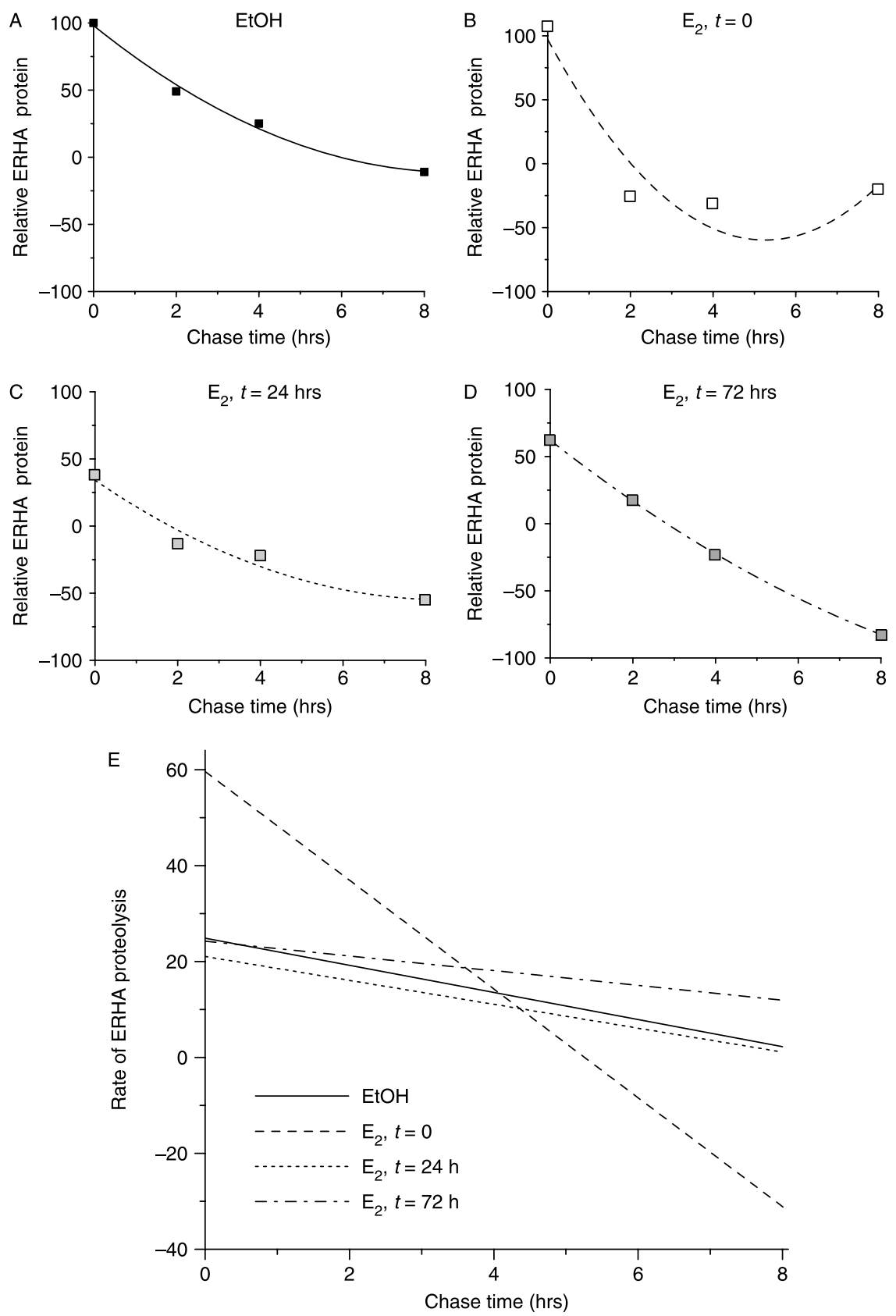

Figure 4 Modulation of the rate of $\mathrm{ER} \alpha$ proteolysis with prolonged exposure to estrogen. The change in ERHA protein as a result of proteolysis was calculated by subtracting the total change in ERHA protein for cells treated with $\mathrm{EtOH}(\mathrm{A}), \mathrm{E}_{2}, t=0(\mathrm{~B}), \mathrm{E}_{2}, t=-24(\mathrm{C})$, and $\mathrm{E}_{2}, t=-72(\mathrm{D})$. The data used to generate the graph can be found in Supplemental Table 1. Data shown are the linear trend lines. Trend lines using second-order polynomial equations were fit to the calculated data points. The $r^{2}$ correlation coefficients for each trend line were $>0.95$, with the exception of $\mathrm{E}_{2}, t=0$ group with a $r^{2}$ value of 0.91 . (E) The rate of proteolysis was calculated for each group by taking the first derivative of the ERHA protein trend line with respect to time, $\mathrm{d}(\mathrm{ERHA}$ protein)/dt, from the proteolysis data trend lines in A-D. The resulting graph illustrates the rate of proteolysis between 0 and $8 \mathrm{~h}$ for each group. 
Another possibility is that over time there is an accumulation of a proteasome-resistant isoform of $\mathrm{ER} \alpha$. We previously demonstrated that residue, S118, in the N-terminal AF-1 of ER $\alpha$ was essential for estrogeninduced proteolysis. S118 is phosphorylated in response to estrogen as well as other intracellular kinase cascades such as MAPK and TFIIH/CDK7 (LeGoff et al. 1994, Kato et al. 1995, Chen et al. 2000). We examined the phosphorylation status of ER $\alpha$ at $\mathrm{S} 118$ by western blot analysis in samples from pulse-chase experiments from three groups representing vehicle-treated $(\mathrm{EtOH})$, acutely estrogen-treated $\left(\mathrm{E}_{2}, t=0\right)$, and chronically estrogen-treated $\left(\mathrm{E}_{2}, t=72\right)$ cells. Samples were assessed at the beginning of the chase period and $4 \mathrm{~h}$ later. As is clear from Fig. 5A, ER $\alpha$ phosphorylation at S118 is weakly detectable in control samples and samples treated with estrogen for $4 \mathrm{~h}$. However, at $72 \mathrm{~h}$, there is a dramatic increase in phosphorylated receptor. Examination of $\mathrm{ER} \alpha$ (lower panel) confirms that following withdrawal from Dox, ER $\alpha$ levels are diminished in control samples and estrogen accelerates the loss of receptor. In contrast, $\mathrm{ER} \alpha$ is stable in cells pretreated with estrogen for $72 \mathrm{~h}$, and the increased stability correlates with the increased level of phosphorylation of receptor at $\mathrm{S} 118$.

To test the causal relationship between phospho-S118 $\mathrm{ER} \alpha$ with increased receptor stability under conditions of prolonged estrogen exposure, we created a stable tet-inducible MCF7 cell line that overexpresses S118E-ERHA in response to Dox. Figure 5B shows a representative screen of three colonies isolated following selection in puromycin in the absence and presence of Dox. Clone \#2 showed the greatest induction in response to Dox and was chosen for further analysis. If increased levels of phospho-S118 ER were responsible for the long half-life of receptor following $72 \mathrm{~h}$ of estrogen treatment, then one might predict that the S118E-ERHA would phenocopy the long half-life of the wild-type receptor under the same conditions. Following the same protocol used for wildtype ERHA in Fig. 1, tet-inducible S118E-ERHA cells were pretreated with estrogen for $72 \mathrm{~h}$. Cells then received a pulse of Dox and the decay of the S118EERHA was followed by western blot analysis using an antibody that recognizes the HA-tagged receptor. Figure 5C shows the decay of S118E-ERHA protein following removal of Dox. For comparison, the data are superimposed on results from Fig. 1B obtained in cells expressing wild-type receptor (ERHA). The turnover rates of $\mathrm{S} 118 \mathrm{E}$ and wild-type receptor are equivalent in cells chronically exposed to estrogen. These data support the idea that phosphorylated ER $\alpha$ accumulates yielding a stable receptor population that can be mimicked by mutation by the phosphomimetic mutant S118E.

\section{Discussion}

The presence of ER $\alpha$ protein in cells is essential for conferring estrogen responsiveness, and it is through the modulation of receptor levels that cells tune their sensitivity to hormone. Estrogen concentrations can vary, but generally, cells are continuously exposed to estrogen if at low levels. Accordingly, this places a constant negative pressure to limit ER $\alpha$ concentrations. Yet, under conditions of chronic hormone exposure, $\mathrm{ER} \alpha$ is not lost. Instead a steady-state level of receptor is achieved. Our data demonstrate that receptor protein levels are sustained in part through a combination of decreased rate of proteolysis and the accumulation of a proteasome-resistant, phosphorylated form of ER $\alpha$. The coordination of these activities is regulated in a time-dependent manner. Based on our findings, we propose that like transcriptional responses to estrogen, $\mathrm{ER} \alpha$ proteolysis is regulated through a temporally controlled sequence of events. Estrogen binding induces the ubiquitination of $\mathrm{ER} \alpha$, targeting a fraction of receptors for degradation by the proteasome. Simultaneously, estrogen induces the phosphorylation of receptor at S118, which can protect receptor from proteolysis, but which accounts for a small proportion of the total receptor pool. By $24 \mathrm{~h}$, the rate of proteolysis is decreased, approximating that of basal conditions in the absence of estrogen. Between 24 and $72 \mathrm{~h}$, the phosphorylated form of ER $\alpha$ has accumulated to sufficient levels to further increase the stability of the general receptor population. This gradual stabilization of receptor would confer protection against depletion of cellular receptors and contribute to the establishment of steady-state levels of ER $\alpha$ when cells are chronically exposed to estrogen.

The idea that changes in ER $\alpha$ protein levels over time can be represented as a function of synthesis and proteolysis is an application of the source-sink method used to describe and quantify dynamic systems. This method dissects dynamic systems, such as the change in $\mathrm{ER} \alpha$ protein levels over time, into the sum of its sources $(\mathrm{ER} \alpha$ protein synthesis) minus the sum of its sinks (ER $\alpha$ proteolysis). There are three possible outcomes: 1) The sum of sources is greater than the sum of sinks resulting in protein accumulation, 2) the sum of sources is less than the sum of sinks resulting in protein reduction, and 3) the sum of sources is equal to the sum of sinks resulting in steady-state levels with no change over time. While this system assumes that $\mathrm{ER} \alpha$ protein has one source and one sink, protein synthesis and proteolysis respectively, the method can be used on a variety of molecules with numerous sources and sinks with each influencing total changes over time. Based on this model, we calculated the rate of proteolysis at different times of estrogen treatment. We observed a decreased rate of proteolysis by 24 and $72 \mathrm{~h}$ relative to initial estrogen exposure. 


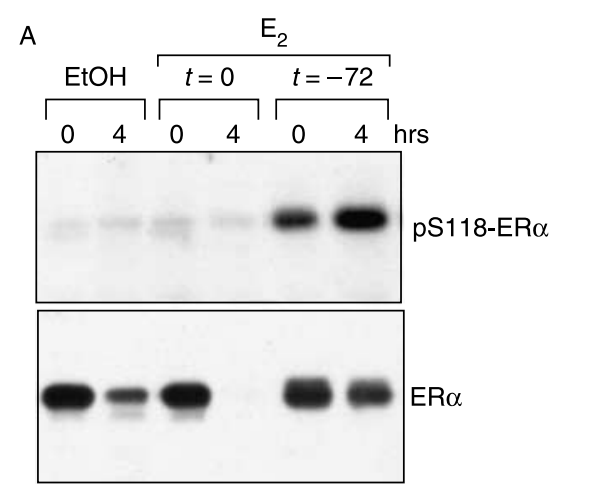

B
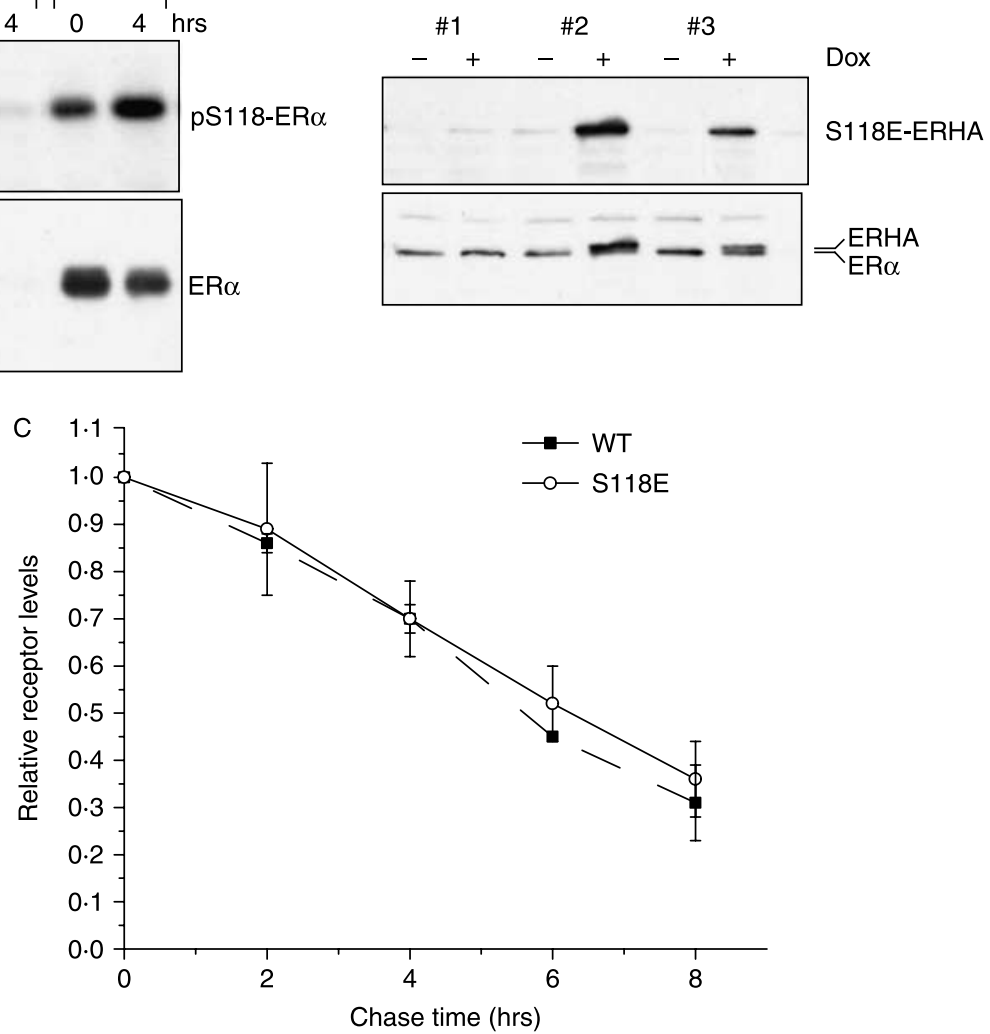

Figure 5 Increased stability of $\mathrm{ER} \alpha$ under chronic estrogen conditions is related to phosphorylation of receptor on S118. (A) Cells were treated as described in Fig. 1A for groups treated acutely $(t=0)$ or chronically $(t=-72)$ with estrogen. Controls included cells treated with vehicle $(\mathrm{EtOH})$. Samples were collected at 0 and $4 \mathrm{~h}$ of the chase period. Western blots were performed on whole cell lysates and probed using anti-pS118 ER $\alpha$ antibody (top panel) and anti-ER $\alpha$ antibody (HC20; bottom panel). Shown is a representative western blot. (B) Tet-inducible MCF7 cell line was created to overexpress HA-tagged $\mathrm{S} 118 \mathrm{E}-\mathrm{ER} \alpha(\mathrm{S} 118 \mathrm{E}-\mathrm{ERHA})$ as described in Materials and methods. Clones were treated with $1 \mu \mathrm{M}$ Dox for $24 \mathrm{~h}$ and screened for expression of S118E-ERHA by western blot analysis using anti-HA primary antibody (top panel) and anti-ER $\alpha$ antibody (bottom panel). Shown is an example of a western blot screen of three clones. Clone 2, with the highest level of induction, was utilized in the subsequent experiments. (C) Tetinducible pulse-chase analysis was carried out on S118E-ERHA clone 2 following $72 \mathrm{~h}$ of pre-exposure to estrogen $\left(\mathrm{E}_{2}, t=-72\right)$. Cells were harvested at $0,2,4,6$, and $8 \mathrm{~h}$ following the removal of Dox in the continued presence of estrogen. Relative changes in S118E-ERHA were determined by quantitative western blot analysis as described in Materials and methods. For comparison, data from tet-inducible pulsechase analysis of the wild-type ERHA from Fig. 1C is also shown.

The data indicate that the rate of proteolysis at later time points was similar to that of the basal turnover rate of receptor in the absence of ligand. Studies by Tateishi et al. (2004) showed that the basal degradation of receptor is mediated through the ubiquitin-proteasome pathway. Further, it was demonstrated that the basal degradation pathway was distinct from estrogen-induced proteolysis and involved the ubiquitin ligase, C-terminus Hsp 70 interacting protein (CHIP). CHIP ligase is a heat shock protein-associated ligase that is found in complex with the unliganded receptor (Connell et al. 1999, Fan et al. 2005). Binding of estrogen disrupts ER $\alpha$ interactions with CHIP ligase and facilitates $\mathrm{ER} \alpha$ interactions with other
E3-ligases that ubiquitinate and bring substrate to the 26S proteasome. We tested whether ER $\alpha$ degradation reverted back to the basal degradation pathway by performing co-immunoprecipitations between $\mathrm{ER} \alpha$ and CHIP ligase. We did not observe an increase in CHIP:ER interactions between 2 and $24 \mathrm{~h}$ of estrogen treatment, though the unliganded receptor co-immunoprecipitated with CHIP ligase (data not shown). Thus, at this point, the reason behind the slowed rate of proteolysis is unclear, but it is of interest for further experimentation since it implies that the proteolytic pathway is subject to additional regulatory events over time in the presence of estrogen. 
The phosphorylation status of ER $\alpha$ plays an important role in the regulation of receptor protein stability. This is also the case for other nuclear receptors, including progesterone receptor, retinoic acid receptor- $\alpha$, and peroxisome proliferator-activated receptor- $\alpha$ (Kopf $e t$ al. 2000, Lange et al. 2000, Blanquart et al. 2002). However, there is conflicting data as to whether phosphorylation stimulates or inhibits degradation. Multiple agents that activate or inhibit phosphorylation impact ER $\alpha$ proteolysis (Borras et al. 1994, Alarid et al. 2003, Henrich et al. 2003, Marsaud et al. 2003, Calligé et al. 2005). Curcumin, a broad spectrum kinase inhibitor, diminishes ER $\alpha$ phosphorylation and inhibits $\mathrm{ER} \alpha$ proteolysis (Calligé et al. 2005). Like curcumin, okadaic acid inhibits ER $\alpha$ degradation; however, in contrast, okadaic acid increases ER $\alpha$ phosphorylation (Borras et al 1994). Other examples show that inhibition of the protein kinase $\mathrm{C}$ (PKC) pathway prevents or has no effect on $\mathrm{ER} \alpha$ degradation, while inhibition of PKA or MAPK accelerates receptor turnover (Marsaud et al. 2003). TPA, 12-O-tetradecanolyphorbol-13 acetate, an upstream activator of PKC, and MAPK have previously been shown to phosphorylate ER $\alpha$ on S118 (LeGoff et al. 1994, Kato et al. 1995). Mutational analysis from our laboratory also showed that mutation of S118 to either alanine or glutamic acid results in stabilization of $\mathrm{ER} \alpha$ in the presence of estrogen (Valley et al. 2005). Thus, the relationship between phosphorylation of ER $\alpha$ and proteolysis is complex and not well defined. The studies presented here show that long-term estrogen treatment results in an increase in ER $\alpha$ half-life that correlates with the increase in phospho-S118 ER $\alpha$. We also demonstrate that the phosphomimetic mutant, S118E, has a long half-life which mirrors that of the wildtype receptor under conditions of chronic estrogen treatment. Together, these data suggest that ER $\alpha$ is stabilized by phosphorylation on S118, but this effect was observed in the context of chronic estrogen treatment. Thus, whether phosphorylation facilitates or inhibits proteolysis appears to be dependent on both cell context and time.

The dynamic control of cellular ER $\alpha$ concentration is physiologically important. Negative regulation of $E R \alpha$ in the presence of estrogen is critical in limiting cellular response to hormone. It has been demonstrated in vitro, in vivo, and in clinical studies that persistent high levels of $\mathrm{ER} \alpha$ have the potential to alter receptor transcriptional function and are associated with pathologies including breast cancer and infertility (Lessey et al. 1989, Khan et al. 1999, Frech et al. 2005, Fowler et al. 2006). Equally important is the requirement to sustain receptor levels to maintain sensitivity to changes in the endocrine environment. The mechanisms that control fluctuating levels of $\mathrm{ER} \alpha$ protein represent a balance between those that increase receptor protein synthesis and those that degrade it. Here, we show that the estrogen-dependent proteolytic control of $\mathrm{ER} \alpha$ is itself subject to regulation by factors that vary with time. Under steady-state conditions, $\mathrm{ER} \alpha$ is a relatively stable protein with a constant slow rate of proteolysis. This raises interesting questions about the potential role of protein stability in the control of specific $\mathrm{ER} \alpha$ functions but also emphasizes the likelihood that such roles, once identified, may be related to temporal responses to estrogen.

\section{Acknowledgements}

This manuscript is dedicated to Dr Jack Gorksi, whose input was invaluable and who we dearly miss. Also, we thank Brian Kenealy for the technical support. This work is funded by a grant from NIH to ETA, DK 64034. The authors declare that there is no conflict of interest that would prejudice the impartiality of this scientific work.

\section{References}

Alarid ET 2006 Lives and times of nuclear receptors. Molecular Endocrinology 20 1972-1981.

Alarid ET, Bakopoulos N \& Solodin N 1999 Proteasome-mediated proteolysis of estrogen receptor: a novel component in autologous down-regulation. Molecular Endocrinology 13 1522-1534.

Alarid ET, Preisler-Mashek MT \& Solodin NM 2003 Thyroid hormone is an inhibitor of estrogen-induced degradation of estrogen receptor- $\alpha$ protein: estrogen dependent proteolysis is not essential for receptor transactivation function in the pituitary. Endocrinology 144 3469-3476.

Blanquart C, Barbier O, Fruchart J-C, Staels B \& Glineur C 2002 Peroxisome proliferator-activated receptor $\alpha(\operatorname{PPAR} \alpha)$ turnover by the ubiquitin-proteasome system controls the ligand-induced expression level of its target genes. Journal of Biological Chemistry 227 $37254-37259$

Borras M, Hardy L, Lempereur F, El Khissiin AH, Legros N, GolWinkler R \& Leclercq G 1994 Estradiol-induced down-regulation of estrogen receptor. Effect of various modulators of protein synthesis and expression. Journal of Steroid Biochemistry and Molecular Biology 48 325-336.

Calligé M, Kieffer I \& Richard-Foy H 2005 CSN5/Jab1 is involved in ligand-dependent degradation of estrogen receptor $\alpha$ by the proteasome. Molecular and Cellular Biology 25 4349-4358.

Chen D, Riedl T, Washbrook E, Pace PE, Coombes RC, Egly J-M \& Ali S 2000 Activation of estrogen receptor a by S118 phosphorylation involves a ligand-dependent interaction with TFIIH and participation of cdk7. Molecular Cell 6 127-137.

Cidlowski JA \& Muldoon TG 1978 The dynamics of intracellular estrogen receptor regulation as influenced by $17 \beta$-estradiol. Biology of Reproduction 18 234-246.

Connell P, Ballinger CA, Jiang J, Wu Y, Thompson LJ, Yin LY \& Patterson C 1999 Identification of CHIP, a novel tetratricopeptide repeat-containing protein that interacts with heat shock proteins and negatively regulates chaperone functions. Nature Cell Biology 3 93-96.

Eckert RL, Mullick A, Rorke EA \& Katzenellenbogen BS 1984 Estrogen receptor synthesis and turnover in MCF-7 breast cancer cells measured by a density shift technique. Endocrinology 114 629-637.

El Khissiin A \& Leclercq G 1999 Implication of proteasome in estrogen receptor degradation. FEBS Letters 448 160-166.

Fan M, Park A \& Nephew KP 2005 CHIP (carboxyl terminus of Hsc70interacting protein) promotes basal and geldanamycin-induced degradation of estrogen receptor-alpha. Molecular Endocrinology 12 2901-2914 
Fowler AM, Solodin N, Preisler-Mashek MT, Zhang P, Lee AV \& Alarid ET 2004 Increases in estrogen receptor- $\alpha$ concentration in breast cancer cells promote serine 118/104/106-independent AF-1 transactivation and growth in the absence of estrogen. FASEB Journal 18 81-93.

Fowler AM, Solodin NM, Valley CC \& Alarid ET 2006 Altered target gene regulation controlled by estrogen receptor- $\alpha$ concentration. Molecular Endocrinology 20 291-301.

Frasor J, Danes JM, Komm B, Chang KCN, Lyttle CR \& Katzenellenbogen BS 2003 Profiling of estrogen up- and down-regulated gene expression in human breast cancer cells: insights into gene networks and pathways underlying estrogenic control of proliferation and cell phenotype. Endocrinology 144 4562-4574.

Frech MS, Halama ED, Tilli MT, Singh B, Gunther EJ, Chodosh LA, Flaws JA \& Furth PA 2005 Deregulated estrogen receptor $\alpha$ expression in mammary epithelial cells of transgenic mice results in the development of ductal carcinoma in situ. Cancer Research 65 681-685.

Gossen M, Greundlieb S, Bender G, Muller G, Hillen W \& Bujard H 1995 Transcriptional activation by tetracyclines in mammalian cells. Science 268 1766-1769.

Henrich LM, Smith JA, Kitt D, Errington TM, Nguyen B, Traish AM \& Lannigan DA 2003 Extracellular signal-regulated kinase 7, a regulator of hormone-dependent estrogen receptor destruction. Molecular and Cellular Biology 23 5979-5988.

Hewitt SC, Deroo BJ, Hansen K, Collins J, Grissom S, Afshari CA \& Korach KS 2003 Estrogen receptor-dependent genomic responses in the uterus mirror the biphasic physiological response to estrogen. Molecular Endocrinology 17 2070-2083.

Horigome T, Ogata F, Golding TS \& Korach KS 1988 Estradiolstimulated proteolytic cleavage of the estrogen receptor in mouse uterus. Endocrinology 123 2540-2548.

Kaneko K, Furlow JD \& Gorski J 1993 Involvement of the coding sequence for the estrogen receptor gene in autologous liganddependent down-regulation. Molecular Endocrinology 7 879-888.

Kato S, Endoh H, Masuhiro Y, Kitamoto T, Uchiyama S, Sasaki H, Masushige S, Gotoh Y, Nishida E, Kawashima H et al. 1995 Activation of the estrogen receptor through phosphorylation by mitogenactivated protein kinase. Science 270 1491-1494.

Keaveney M, Parker MG \& Gannon F 1993 Identification of a functional role for the $3^{\prime}$ region of the human oestrogen receptor gene. Journal of Molecular Endocrinology 10 143-152.

Khan SA, Sachdeva A, Naim S, Meguid MM, Marx W, Simon H, Halverson JD \& Numann PJ 1999 The normal breast epithelium of women with breast cancer displays an aberrant response to estradiol. Cancer Epidemiology, Biomarkers and Prevention 8 867-872.

Kopf E, Plassat J-L, Vivat V, de The H, Chambon P \& Rochette-Egly C 2000 Dimerization with retinoid X receptors and phosphorylation modulate the retinoic acid-induced degradation of retinoic acid receptors alpha and gamma through the ubiquitin-proteasome pathway. Journal of Biological Chemistry 275 33280-33288.

Lange CA, Shen T \& Horwitz KB 2000 Phosphorylation of human progesterone receptors at serine-294 by mitogen-activated protein kinase signals their degradation by the $26 \mathrm{~S}$ proteasome. PNAS $\mathbf{9 7}$ 1032-1037.

LeGoff P, Montano MM, Schodin DJ \& Katzenellenbogen BS 1994 Phosphorylation of the human estrogen receptor. Identification of hormone-regulated sites and examination of their influence on transcriptional activity. Journal of Biological Chemistry 1994 4458-4466.

Lessey BA, Metzger DA, Haney AF \& McCarty KS 1989 Immunohistochemical analysis of estrogen and progesterone receptors in endometriosis: comparison with normal endometrium during the menstrual cycle and the effect of medical therapy. Fertility and Sterility 51 409-415.

Livak KJ \& Schmittgen TD 2001 Analysis of relative gene expression data using real-time quantitative PCR and the $2^{-\Delta \Delta C_{\mathrm{T}}}$ method. Methods 25 402-408.
Lonard DM, Nawaz Z, Smith CL \& O'Malley BW 2000 The 26S proteasome is required for estrogen receptor-a and coactivator turnover and for efficient estrogen receptor- $\alpha$ transactivation. Molecular Cell 5 939-948.

Marsaud V, Gougelet A, Maillard S \& Renoir J-M 2003 Various phosphorylation pathways, depending on agonist and antagonist binding to endogenous estrogen receptor a $(\mathrm{ER} \alpha)$ differentially affect ER $\alpha$ extractability, proteasome-mediated stability, and transcriptional activity in human breast cancer cells. Molecular Endocrinology 17 2013-2027.

Métivier R, Penot G, Hübner MR, Reid G, Brand H, Koš M \& Gannon F 2003 Estrogen receptor- $\alpha$ directs ordered, cyclical, and combinatorial recruitment of cofactors on a natural target promoter. Cell 115 751-763.

Monsma FJ Jr, Katzenellenbogen BS, Miller MA, Ziegler YS \& Katzenellenbogen JA 1984 Characterization of the estrogen receptor and its dynamics in MCF-7 human breast cancer cells using a covalently attaching antiestrogen. Endocrinology 115 143-153.

Nawaz Z, Lonard DM, Dennis AP, Smith CL \& O'Malley BW 1999 Proteasome-dependent degradation of the human estrogen receptor. PNAS 96 1858-1862.

Pakdel F, Le Goff P \& Katzenellenbogen BS 1993 An assessment of the role of domain $\mathrm{F}$ and PEST sequences in estrogen receptor half-life and bioactivity. Journal of Steroid Biochemistry and Molecular Biology 46 663-672.

Pink JJ \& Jordan VC 1996 Models of estrogen receptor regulation by estrogens and antiestrogens in breast cancer cell lines. Cancer Research 56 2321-2330.

Preisler-Mashek MT, Solodin N, Stark BL, Tyriver MK \& Alarid ET 2002 Ligand-specific regulation of proteasome-mediated proteolysis of estrogen receptor- $\alpha$. American Journal of Physiology. Endocrinology and Metabolism 282 E891-E898.

Read LD, Greene GL \& Katzenellenbogen BS 1989 Regulation of estrogen receptor messenger ribonucleic acid and protein levels in human breast cancer cell lines by sex steroid hormones, their antagonists, and growth factors. Molecular Endocrinology 3 295-304.

Reid G, Hubner MR, Metivier R, Heike B, Denger S, Manu D, Beaudouin J, Ellenberg J \& Gannon F 2003 Cyclic, proteasomemediated turnover of unliganded and liganded ER $\alpha$ on responsive promoters is an integral feature of estrogen signaling. Molecular Cell 11 695-707.

Saceda M, Lippman ME, Lindsey RK, Puente M \& Martin MB 1989 Role of an estrogen receptor-dependent mechanism in the regulation of estrogen receptor mRNA in MCF-7 cells. Molecular Endocrinology 3 1782-1787.

Shang Y, Hu X, DiRenzo J, Lazar MA \& Brown M 2000 Cofactor dynamics and sufficiency in estrogen receptor-regulated transcription. Cell 103 843-852.

Tateishi Y, Kawabe Y, Chiba T, Murata S, Ichikawa K, Murayama A, Tanaka K, Baba T, Kato S \& Yanagisawa J 2004 Ligand-dependent switching of ubiquitin-proteasome pathways for estrogen receptor. EMBO Journal 23 4813-4823.

Valley CC, Metivier R, Solodin NM, Fowler AM, Mashek MT, Hill L \& Alarid ET 2005 Differential regulation of estrogen-inducible proteolysis and transcription by the estrogen receptor $\alpha$ N-terminus. Molecular and Cellular Biology 25 5417-5428.

Wijayaratne AL \& McDonnell DP 2001 The human estrogen receptor$\alpha$ is a ubiquitinated protein whose stability is affected differentially by agonists, antagonists and selective estrogen receptor modulators. Journal of Biological Chemistry 276 35684-35692.

Received in final form 13 November 2007

Accepted 14 November 2007

Made available online as an Accepted Preprint 14 November 2007 